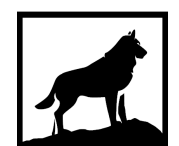

Michigan Technological

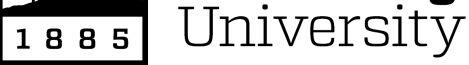

Michigan Technological University Digital Commons @ Michigan Tech

2017

CHARACTERIZATION OF GENIC MICROSATELLITE MARKERS (EST-SSRS) IN THE ENDANGERED OAK SPECIES QUERCUS GEORGIANA M.A.CURTIS

Priyanka Dipak Kadav

Michigan Technological University, pdkadav@mtu.edu

Copyright 2017 Priyanka Dipak Kadav

Recommended Citation

Kadav, Priyanka Dipak, "CHARACTERIZATION OF GENIC MICROSATELLITE MARKERS (EST-SSRS) IN THE ENDANGERED OAK SPECIES QUERCUS GEORGIANA M.A.CURTIS", Open Access Master's Report, Michigan Technological University, 2017.

https://doi.org/10.37099/mtu.dc.etdr/310

Follow this and additional works at: https://digitalcommons.mtu.edu/etdr

Part of the Forest Biology Commons, Forest Management Commons, and the Molecular Genetics Commons 


\title{
CHARACTERIZATION OF GENIC MICROSATELLITE MARKERS (EST-SSRS) IN THE ENDANGERED OAK SPECIES QUERCUS GEORGIANA M.A.CURTIS
}

\author{
By
}

Priyanka Dipak Kadav

\begin{abstract}
A REPORT
Submitted in partial fulfillment of the requirements for the degree of MASTERS OF SCIENCE
\end{abstract}

In Forest Molecular Genetics and Biotechnology

MICHIGAN TECHNOLOGICAL UNIVERSITY

2017

(C2017 Priyanka Dipak Kadav 
This report has been approved in partial fulfillment of the requirements for the Degree of MASTER OF SCIENCE in Forest Molecular Genetics and Biotechnology.

School of Forest Resources and Environmental Science

Report Advisor: Dr. Oliver Gailing

Committee Member: Dr. David Flaspohler

Committee Member: Dr. Hairong Wei

School Dean: Dr. Terry Sharik 


\section{Table of Contents}

1. List of Figures and Tables......................................................

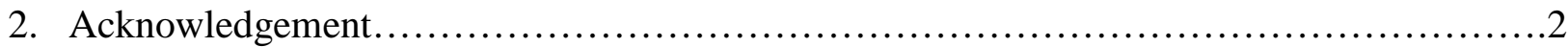

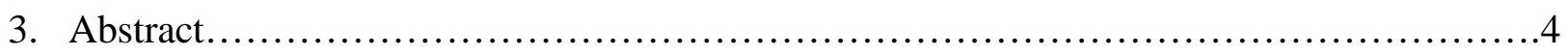

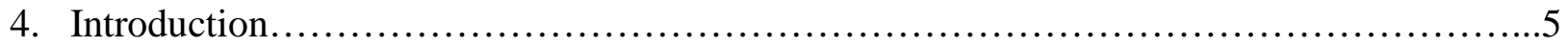

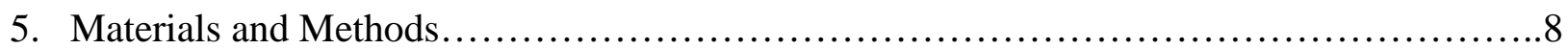

6. Results.......................................................................

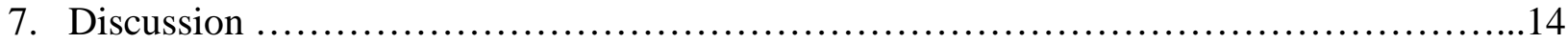

8. Conclusion....................................................................

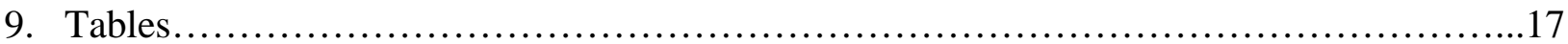

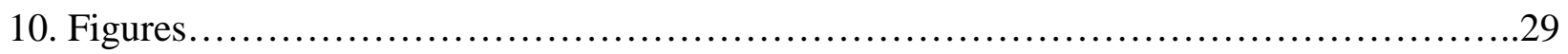

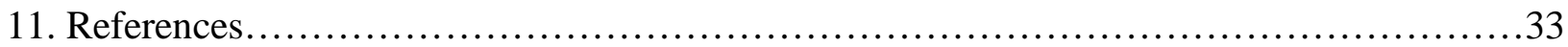




\section{List of Tables and Figures}

Table 1. Sampled Quercus georgiana populations.

Table 2. Description of genic EST-SSRs.

Table 3. Mean genetic variation values for each marker across all samples

Table 4. Mean genetic variation estimates for each population

Table 5. HWE exact tests by locus in each population.

Table 6. Pairwise genetic distance $\left(\mathrm{F}_{\mathrm{ST}}\right)$ between populations.

Table 7. Pairwise geographic distance in kilometers between populations.

Figure 1. Geographic distance (measured in kilometers) versus genetic distance for pairwise comparisons of nine populations of Quercus georgiana using a Mantel test.

Figure 2. Genetic assignment of individuals using the Bayesian method in STRUCTURE 2.3.4

Figure 3. Dendrogram (Neighbor joining method) based on Cavalli-Sforza and Edwards (1967) genetic distances at EST-SSRs.

Figure 4. Geographic distribution of percentage of ancestry per population as inferred in STRUCTURE. 


\section{Acknowledgement}

Heartily, I express my sincere gratitude to the Almighty for showering blessing upon me and giving me the strength to do the research work.

First and foremost, I am grateful to my guide Prof. Oliver Gailing for his constant support and guidance. His guidance aided me to learn about research in its true sense. He paid invaluable time and painstaking effort throughout my project work. It was my privilege to work with him. I am extremely thankful to him who gave me this opportunity to carry out research and meeting with the highly skilled scientists in the laboratory.

I am grateful to The Morton Arboretum and Chicago Botanical Garden for offering this project and The Morton Arboretum and Ecosystem Science Centre for funding me.

My grateful thanks to our lab manager Dr. Jennifer Sanders for her espouse during the project work.

Sincere thanks to my committee members Dr. David Flaspohler and Dr. Hairong Wei.

I would like to acknowledge the timely help provided by Sudhir Khodwekar for his continuous encouragement and right direction towards the goal. He stood beside me as a pillar throughout my research journey. Things would have been difficult without his constant support. I would like to thank Munkaila Mussah for encouraging me to do my research and who took care of me considering as his little sister.

My family has given me constant and unequivocal support throughout this journey. My mother has always been my strength and inspiration and her belief in me made this journey successful. My uncle Prashant Deshpande back in Abu Dhabi has always been my support in this journey. 
Last but not the least; I would like to thank my friends Monica Harmon, Ruhua Zhang, Sirikorn Khumwan, Mehmet Acet, Roba Bdeir and Robert Richard for accompanying me during the journey.

Practical experience is a prerequisite in today’s generation. The laboratory work provided me with immense knowledge. It was a memorable journey that will always remain evergreen in my mind. 


\begin{abstract}
Quercus is important ecologically and economically because it provides food and habitat for wildlife, wood and paper products for humans. Oaks are endangered due to various factors like shifting climates, habitat loss, drought, pathogens and genetic swamping. Quercus georgiana (M.A. Curtis) is an endangered and restricted oak species which is remaining only in the southeastern part of the US. Efforts are required to conserve this endangered species from extinction. Conservation of this species can be done through these methods: ex-situ conservation (arboretum and botanical garden) and in-situ conservation strategies which protect the species in its natural habitat. For this conservation strategy, it is important to ensure that sample collections capture as much of the gene pool as possible so that the biodiversity is maintained. A variety of molecular markers are available for Quercus. These markers which are highly polymorphic, co-dominant and multiallelic loci will be useful in the study of population genetics of Q. georgiana. Genetic variations in both, among and within the populations, have to be considered if sampling and conservation strategies are developed for this rare and endangered species. These analyses are important in the future for sample collection trips so that the conservation goal is obtained.
\end{abstract}




\section{Introduction}

Deforestation, pollution, and climate change are threatening the forest diversity all over the world (Ledig 1988). Since forests are the habitats for diverse organisms, the threat to forest diversity is extended to these flora and fauna that are associated with forests and not only the forest trees. When a species becomes extinct, along with that much of the genetic diversity is lost too upon which long-term survival and evolution depend. Genetic variation is essential for a population in order to adapt to the environment and survive (Reed, Frankham 2003). Once a species or a population with a unique genetic information has been lost, it cannot be restored. The protection of endangered species and its genes for future generations is important to maintain the genetic diversity in a species (Ledig 1988). Therefore, conservation biology plays an important role in the preservation of these genes. The field of conservation biology is dealing with scientific knowledge useful to preserve biodiversity. A great deal of effort in conservation biology has focused on conservation genetics. Conservation efforts are usually classified as in-situ and ex-situ, meaning in the natural position (or in place) and out of the natural position, respectively.

\section{Quercus georgiana}

According to Botanic Gardens Conservation International (BGCI US), 17 species of oaks in the US are endangered like Quercus acerifolia (Palmer), Quercus alba (U. S. P), Quercus hinckleyi (C. H. Muller), Quercus georgiana (M. A. Curtis). Quercus georgiana is an endangered US endemic oak species that is left in only a few populations of the Piedmont region in the southeastern US (GA, AL, and NC). There are 14 counties of this species in Georgia and 3 counties in Alabama. There are only five individual trees of the entire population that are remaining in North Carolina and the remnant 
populations in the South Carolina which are considered to be the part of the historic range of this species are now eliminated (Oldfield, S. and A. Eastwood 2007). Quercus georgiana is important from both ecological and economic perspectives. Quercus georgiana has ornamental value because of its glossy green leaves, attractive autumn colors of purples and reds and its resilience to drought and heat. Its leaves and acorns are food sources for larvae and woodpeckers, deers and small mammals (Toppila 2012). Oaks are anemophilous i.e. gene flow occurs by wind pollination.

\section{Threats}

Tourism and recreation are major threats to Q. georgiana. This species is present at popular hiking trails within state parks and nature reserves at Stone Mountain. Erosion, poor regeneration, climate change, drought conditions and compacted soils that result in foot and vehicle traffic on granite outcrops are also major reasons of threats. Genetic swamping and introgression from surrounding red oak species such as Quercus (section Lobatae) results in the threatening of the genetic identity of Quercus georgiana (Wenzell 2015).

\section{Molecular methods}

Molecular tools such as microsatellites, RAPDs, AFLPs and chloroplast DNA are used for population genetic studies. Microsatellite markers provide information in genetic analysis studies because of their high polymorphism and co-dominant nature of inheritance (Sertse et al. 2013; Keiper et al. 2003; Stefenon et al. 2008). Microsatellites are multiple repeats of short sequences of DNA which are used to assess genetic variation. The populations of threatened or endangered organisms are analyzed using molecular markers that need to be saved before they go extinct. Expressed Sequence Tags (ESTs) are 
rich sources of SSRs which are often not only polymorphic within the source taxon, but in related taxa, as well (Ellis \& Burke 2007).

\section{$\underline{E x \text {-situ and In-situ conservation of exceptional species }}$}

Quercus georgiana is an 'exceptional species'. The seeds of this species cannot be banked because acorns will not survive long-term dry storage. Research is going on for the acorns of the species which cannot be stored in seed banks using in vitro propagation and cryopreservation as a conservation method (Toppila 2012). Ex-situ collections must target the entire range of individual samples to seize the maximum genetic diversity possible from them. The second method of conservation is the in-situ conservation strategy where the species are protected in its natural habitat.

The Morton Arboretum and Chicago Botanic Garden aims at studying the genetic diversity of $Q$. georgiana from both natural and cultivated collections for future conservation efforts. The main aim of the project is to characterize genic microsatellite markers (EST-SSRs) in this endangered oak species in nine populations in Georgia and Alabama. The sampling from the other populations was not made because Q. georgiana was infrequent and the trees appeared to be hybrids in those populations. Hence, these nine populations are the collection representatives that cover the distribution range of the species. The overall goal is to perform genetic variation analyses using Q. georgiana as a case study. Decisions can be made regarding which populations in a species and how many should be conserved which is important in the future, for sample collection trips so that the ex-situ conservation prime mission is obtained that can lead to future reintroduction and restoration efforts (Whitlock 2016). 


\title{
Materials and Methods
}

\author{
Plant Material
}

A total of 215 samples consisting of the nine populations of Quercus georgiana were sampled in Alabama and Georgia (Table 1), and sampled plants were at least five meters apart. Also, the GPS coordinates were recorded for each plant. The nine populations consisted of 24 samples for most populations and 23 samples for one population (Stone Mountain).

\section{Marker analyses}

A total of 27 genic microsatellites (Expressed Sequence Tag- Simple Sequence Repeats, EST-SSRs) originally developed and genetically mapped in Quercus robur (Durand et al. 2010; Bodénès et al. 2012) were tested in a total of eight samples from four Q. georgiana populations. Markers were selected based on successful transferability to North American oak species of section Lobatae (Lind and Gailing 2013, Sullivan et al. 2013, Lind-Riehl et al. 2014). Twelve of these markers were successfully adopted for use in Q. georgiana and all samples were analyzed at these markers. Functional annotations were assigned to EST-SSRs using the Blast2GO software (Conesa et al. 2005).

PCR amplification followed the protocol described in Lind and Gailing (2013). Specifically, samples were amplified in a GeneAmp PCR system 2700 (Applied Biosystem) with the following program: initial denaturation at $95{ }^{\circ} \mathrm{C}$ for 15 min followed by 35 cycles of denaturation at $94{ }^{\circ} \mathrm{C}$ for 45 sec, annealing at $\mathrm{T}_{\mathrm{a}}$ (Table 2) for $45 \mathrm{sec}$ and extension at $72{ }^{\circ} \mathrm{C}$ for $45 \mathrm{sec}$. The final extension step was for 20 min at $72{ }^{\circ} \mathrm{C}$. Each PCR was performed in a $15 \mu$ reaction mix composed of $5 \mu$ l HotFIREPol (Oak Biotechnologies, containing $10 \mathrm{mM} \mathrm{MgCl}_{2}, 0.6$ units of HOT FIREPol® Taq polymerase, and $2 \mathrm{mM}$ of each dNTP), $2 \mu$ l fluorescently labeled forward primers $(5 \mu \mathrm{M}), 2 \mu$ reverse primers $(5 \mu \mathrm{M}), 2 \mu \mathrm{l}$ DNA ( $\sim 2$ ng), and $4 \mu$ molecular grade ultra-pure water (Phenix Research Labs). The PCR amplicons 
were checked on $2 \%$ agarose gels in $1 \mathrm{x}$ TAE buffer at $200 \mathrm{~V}$ for 20 minutes. Exact fragment sizes of the amplified DNA products were determined on an ABI3730 Genetic Analyzer with the internal size standard GS-LIZ-500 (Applied Biosystems).

\section{$\underline{\text { Data Analysis }}$}

The scoring of the data was done with the software GeneMarker® V2.6.3 (SoftGenetics) and fragments were assigned to bins after careful visual inspection.

\section{$\underline{\text { Genetic diversity analyses }}$}

Genetic variation parameters expected heterozygosity $\left(\mathrm{H}_{\mathrm{e}}\right)$ (Nei 1973), observed heterozygosity $\left(\mathrm{H}_{\mathrm{o}}\right)$ and number of alleles per locus $\left(\mathrm{N}_{\mathrm{a}}\right)$ were calculated in GENAlEx v. 6 (Peakall and Smouse 2006). Also, the number of private alleles and of locally common alleles (found in $\leq 25 \%$ of all populations) was calculated in GENEALEx. For individual markers, the inbreeding coefficient F (Wright 1965) was calculated for all populations. Significant deviation from Hardy-Weinberg proportions was tested in GENEPOP 4.2 (Raymond and Rousset 1995, Rousset 2008) using probability tests for each marker and population. Pairwise genetic differentiation between populations ( $\left.\mathrm{F}_{\mathrm{ST}}\right)$ was calculated and tested for significance in GENEPOP 4.1with the exact G test using default settings (Raymond and Rousset 1995, Rousset 2008). A Mantel test (Mantel 1967) was performed in GENAlEx v. 6 which compares a genetic distance matrix with a geographical distance matrix to test for correlation between genetic distance and geographical location. The Mantel test performs permutations on one matrix while holding the other constant.

\section{Genetic assignment analysis}

STRUCTURE v. 2.3.4 was used to infer population genetic structure using the multi-locus genotype data (Pritchard, Stephens and Donnelly 2000.) The Structure software implements a model-based 
genetic admixture analysis using Bayesian methods to assign individuals to populations. To determine the number of clusters $\mathrm{K}$ that best fit our data, we performed five independent runs with a burn-in period of 30,000 iterations followed by $10^{6}$ iterations for each value of $K(K=1-9)$ under the admixture model with correlated allele frequencies without any prior information regarding species identification. A dendrogram (Neighbor joining method) was created based on Cavalli-Sforza and Edward’s (1967) pairwise genetic distances at EST-SSRs using Populations 2.0 (Langella 1999). Statistical support of clusters was determined with 1,000 bootstrap replicates. TreeViewX (Page 1996) was used to visualize the dendrogram. 


\section{Results}

All twelve microsatellite primers amplified and were polymorphic (Table 3). For individual markers, observed heterozygosity $\left(\mathrm{H}_{0}\right)$ across populations was highest at marker FIR048 and it was found to be 0.838 and expected heterozygosity $\left(\mathrm{H}_{\mathrm{e}}\right)$ across populations was highest at marker FIR043 and it was found to be 0.802 . Marker VIT081 has the lowest observed heterozygosity $\left(\mathrm{H}_{0}\right)$ and expected heterozygosity $\left(\mathrm{H}_{\mathrm{e}}\right)$ values. The mean F values (inbreeding coefficient) was highest at locus GOT037 and it was found to be 0.1924 and the lowest at the locus PIE039 which was found to be -0.1763 (no indication of inbreeding at this marker). The number of alleles per locus ranged from 2 to 9 (Table 3). There was no indication of null alleles in any of the populations. At the population level, CB and AM populations had the highest observed heterozygosity $\left(\mathrm{H}_{\mathrm{o}}\right)$, i.e. 0.567 , and expected heterozygosity $\left(\mathrm{H}_{\mathrm{e}}\right)$, i.e. 0.574 , values whereas PN population had the lowest values of 0.447 and 0.471 , respectively. The mean inbreeding coefficient was highest in population AM (0.116) and lowest in population CR (0.114). It was seen that the F values were not consistently positive at most markers per population. Thus, there was no indication of inbreeding in any of the populations. The number of private alleles and locally common alleles $(\leq 25 \%)$ were also calculated. CB population had the highest number of private and locally common alleles. The number of alleles per population ranged from 3 to 5 (Table 4).

Hardy- Weinberg Exact tests (HWE) were performed by locus in each population. Values in boldface type are significantly different from Hardy-Weinberg proportions $(\alpha=0.05)$ after Bonferroni correction $(p<0.05 / 12=0.00416)$ (Table 5). It was seen that most of the markers did not show significant deviations from Hardy- Weinberg proportions except for marker FIR028 in population ED (positive F value), GOT037 in population AM (positive F value), FIR043 and PIE200 in population CR (negative F values) which were significantly different from Hardy-Weinberg proportions. ANOVA (Analysis of 
Variance) and Posthoc tests were performed which indicate no significant differences in mean $\mathrm{H}_{\mathrm{e}}$, mean $\mathrm{H}_{\mathrm{o}}$ and mean $\mathrm{N}_{\mathrm{a}}$ between populations.

Pairwise genetic distances $\left(\mathrm{F}_{\mathrm{ST}}\right)$ between populations were found to be significant after exact $\mathrm{G}$ test $(\mathrm{p}<0.001)$. The pairwise genetic distance $\left(\mathrm{F}_{\mathrm{ST}}\right)$ values between the populations PN and DK was highest (0.129) (Table 6) and it was seen in the STRUCTURE results that they are not clustered together. Pairwise geographic distances between populations in kilometers were also calculated. But according to the geographic distance, the distance between PN and DK is 57.22 kilometers. The lowest Fst values were between ED and DK and between WG and DK populations indicating that they are genetically related to each other. But according to the geographic distance, the distance between ED and DK is 176.3 kilometers and between WG and DK is 162.98 kilometers. The highest pairwise geographic distance was between WG and MR and it was found to be 420.3 kilometers (Table 7). A Mantel test, based on the correlation between a genetic distance matrix and a geographical distance matrix was performed. The regression coefficient $\mathrm{R}^{2}$ is comparatively low (0.2692) and p value is 0.100 (not significant), indicating that there is no correlation between genetic and geographic distance (Fig. 1).

Genetic assignment analysis performed in STRUCTURE indicated $\mathrm{K}=2$ as the most likely number of genetic clusters (Fig. 2). In each population most individuals were assigned genetically to one of the two clusters such that the first four populations (DK, CB, ED, WG) were grouped in cluster 1 (red) and the remaining five populations (PN, AM, SM, MR, CR) were grouped in cluster 2 (green). The dendrogram (Neighbor joining method) based on Cavalli-Sforza and Edwards (1967) pairwise genetic distances at EST-SSRs revealed low and non-significant bootstrap values for most clusters (bootstrap values $<50$ ). The grouping of populations was not related to their geographic location (Fig. 3). The analysis of population structure identified two distinct genetic clusters, but no association between 
ancestry in one of the clusters and geographic location in one of the three sampled forest fragments was detected (Fig. 4). 


\section{Discussion}

Quercus georgiana was used to study genetic diversity through the use of microsatellites. In this study, genetic variation, measured by mean expected heterozygosity, was analyzed in the endangered species Q. georgiana.

Pairwise genetic distances (FsT) between populations were found to be significant but no correspondence with geographic distances (Fig. 4). There was no association between genetic and geographic distances. Mantel tests also indicated that there is no correlation between genetic and geographic distance (Fig. 1). Though Q. georgiana is discontinuously distributed throughout the Piedmont region because of habitat loss and fragmentation, it might be due to historic gene flow between populations through pollen movement by wind.

Genetic variation of Quercus georgiana was low when compared to another endangered oak species Quercus hinckleyi (C.H. Muller). Quercus hinckleyi is distributed in the Brewster and Presidio counties in Texas (Backs et al. 2016). The genetic variation measured by expected heterozygosity was found to be 0.853 which is high than the genetic variation of Q. georgiana species. The comparison of population genetic diversity between a rare, narrowly distributed species Quercus georgiana and a common, widespread species of Quercus rubra was studied. Northern red oak (Quercus rubra) is widely distributed throughout the eastern part of US. It extends from the Atlantic coast in the east to the Mississippi River in the west and from southern Ontario in the north to central Georgia in the south (Sork et al. 1993; Lind and Gailing 2013). For Quercus rubra, the expected heterozygosity (mean) was 0.71 at EST-SSRs and that of Quercus georgiana was 0.510 (only EST-SSRs were compared for both the species). This indicates the impact of small population size and high isolation on genetic diversity in Quercus georgiana and this data can be used in conservation planning of this endangered species. 
Decisions should be made on the sampling strategy depending upon the level of genetic variation of this endangered species. Since the pairwise genetic differentiation between the populations is significant, sampling from all the populations should be done to incorporate all the genetic diversity for conservation. But considering the limited resources for $e x$-situ conservation strategy, the results of the pairwise genetic differentiation between the populations with higher values can be given priority for conservation purpose. For example, the populations PN, DK, MR, ED and WG should be given priority for conservation since they have high pairwise genetic differentiation values. The STRUCTURE results identify two genetic clusters (Fig. 2) that can be seen in the dendrogram result as well (Fig. 3). For example, the populations DK, CB, ED and WG are clustered together on both the dendrogram and the STRUCTURE diagram. These findings suggest that when building the ex-situ collections at least two populations should be sampled that will represent the two genetic clusters identified in STRUCTURE and dendrogram. Also, in the dendrogram, the populations showing bootstrap values higher than 50\% (statistical support) should be prioritize for sampling i.e. populations DK, ED, WG and CB. AM population has the highest genetic distance (Fig. 3) to all populations and therefore future collections should target AM populations since it is genetically differentiated from the other populations. 


\section{Conclusion}

The present studies utilized wild populations of Quercus georgiana. Genetic variation in wild populations can be compared to that of $e x$-situ collections so that effective conservation plans can be developed of this threatened species to support the in-situ conservation. Results from this study can be used to make decisions regarding the $e x$-situ conservation strategies in this species such that the entire gene pool is captured to maintain high genetic diversity. The ex-situ conservation can support the reintroduction and restoration strategies to enlarge wild plants in their current locations. Conversely, this study can also be a baseline for building and improving the collection of Quercus georgiana in arboretums and botanical gardens. 


\section{Tables}

Table 1. Sampled Quercus georgiana populations.

\begin{tabular}{|c|c|c|c|c|c|c|}
\hline Locality & County & State & $\begin{array}{l}\text { Pop. } \\
\text { Code }\end{array}$ & $\begin{array}{l}\text { Sample } \\
\text { size (n) }\end{array}$ & Latitude & Longitude \\
\hline $\begin{array}{l}\text { Davidson-Arabia Mountain } \\
\text { Nature Preserve }\end{array}$ & DeKalb & GA & AM & 24 & 33.667 & -84.125 \\
\hline $\begin{array}{l}\text { Chattahoochee Bend State } \\
\text { Park }\end{array}$ & Coweta & GA & $\mathrm{CB}$ & 24 & 33.421 & -84.962 \\
\hline Concord Road & Pike & GA & CR & 24 & 33.147 & -84.464 \\
\hline $\begin{array}{l}\text { Dowdell’s Knob, F.F. } \\
\text { Roosevelt State Park }\end{array}$ & Harris & GA & DK & 24 & 32.84 & -84.746 \\
\hline Eden & St. Claire & AL & ED & 24 & 33.64 & -86.369 \\
\hline Moss Rock Preserve & Jefferson & $\mathrm{AL}$ & MR & 24 & 33.384 & -86.841 \\
\hline Penton & Chambers & $\mathrm{AL}$ & $\mathrm{PN}$ & 24 & 33.026 & -85.483 \\
\hline Stone Mountain & DeKalb & GA & SM & 23 & 33.809 & -84.152 \\
\hline Walnut Grove & Walton & GA & WG & 24 & 33.751 & -83.832 \\
\hline
\end{tabular}


Table 2. Description of genic EST-SSRs.

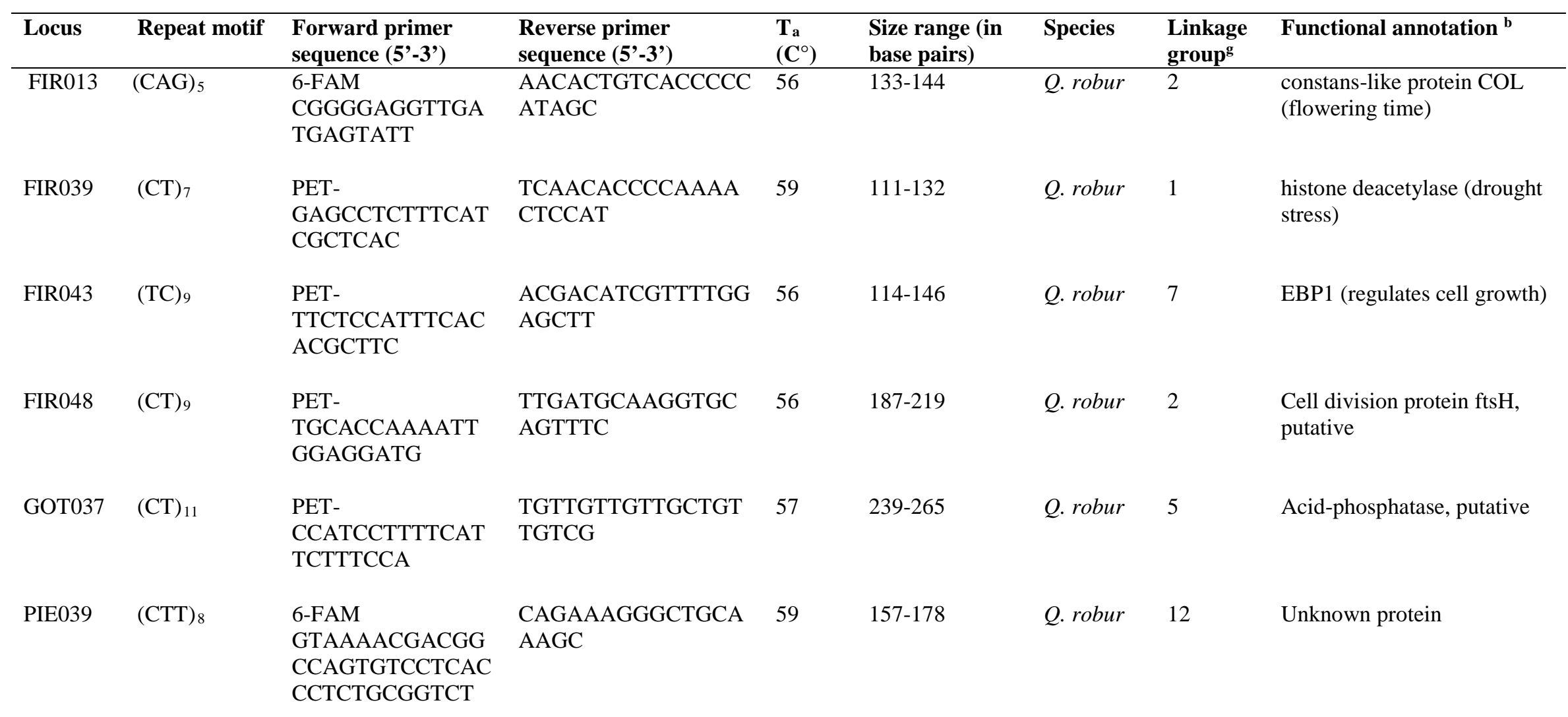




\begin{tabular}{|c|c|c|c|c|c|c|c|c|}
\hline Locus & Repeat motif & $\begin{array}{l}\text { Forward primer } \\
\text { sequence (5'-3') }\end{array}$ & $\begin{array}{l}\text { Reverse primer } \\
\text { sequence (5'-3') }\end{array}$ & $\begin{array}{l}\mathbf{T}_{\mathbf{a}} \\
\left(\mathbf{C}^{\circ}\right)\end{array}$ & $\begin{array}{l}\text { Size range (in } \\
\text { base pairs) }\end{array}$ & Species & $\begin{array}{l}\text { Linkage } \\
\text { groupg }^{\text {groug }}\end{array}$ & Functional annotation ${ }^{b}$ \\
\hline PIE200 & $(\mathrm{CAA})_{5}$ & $\begin{array}{l}\text { 6-FAM } \\
\text { ACAACATGTGCC } \\
\text { AAAACTGC }\end{array}$ & $\begin{array}{l}\text { TCGATGATGTGGTTG } \\
\text { TTGATG }\end{array}$ & 56 & $107-119$ & Q. robur & $\begin{array}{l}\text { Not } \\
\text { assigned }\end{array}$ & $\begin{array}{l}\text { Zinc finger a20 an1 domain- } \\
\text { containing stress-associated } \\
\text { protein 5-like }\end{array}$ \\
\hline PIE125 & $(\text { GGAAGC })_{3}$ & $\begin{array}{l}\text { PET- } \\
\text { AATACAAATCGC } \\
\text { AGGAGGTG }\end{array}$ & $\begin{array}{l}\text { CTAACCCATCGTTCA } \\
\text { TGGAG }\end{array}$ & 57 & $146-162$ & Q. robur & 6 & $\begin{array}{l}\text { chaperone protein dna J, } \\
\text { chloroplast, putative (heat } \\
\text { shock protein, stress) }\end{array}$ \\
\hline FIR035 & $(\mathrm{AT})_{6}$ & $\begin{array}{l}\text { NED- } \\
\text { GCTAAGGTTCCGT } \\
\text { GTTCCAA }\end{array}$ & $\begin{array}{l}\text { GGCCAGCAACTAAA } \\
\text { CCAAGA }\end{array}$ & 56 & $146-152$ & Q. robur & 5 & $\begin{array}{l}\text { chaperone protein dna J, } \\
\text { chloroplast, putative (heat } \\
\text { shock protein, stress) }\end{array}$ \\
\hline FIR028 & $(\mathrm{TC})_{8}$ & $\begin{array}{l}\text { VIC- } \\
\text { GGAAGAGTGTTC } \\
\text { GGAAAGCA }\end{array}$ & $\begin{array}{l}\text { CCAGCTCCTCCACAA } \\
\text { TAGCA }\end{array}$ & 56 & $201-237$ & Q. robur & 1 & $\begin{array}{l}\text { tropinone reductase, putative } \\
\text { (drought stress) }\end{array}$ \\
\hline VIT081 & $(\mathrm{CAT})_{3}$ & $\begin{array}{l}\text { 6-FAM } \\
\text { AATTCAAACCCA } \\
\text { GCCAACTG }\end{array}$ & $\begin{array}{l}\text { TCCTCTGGATGCTCC } \\
\text { ATCA }\end{array}$ & 56 & $112-136$ & Q. robur & $\begin{array}{l}\text { Not } \\
\text { assigned }\end{array}$ & Proline- rich protein \\
\hline VIT086 & $(\mathrm{CAG})_{5}$ & $\begin{array}{l}\text { VIC- } \\
\text { AAGAACACCCAT } \\
\text { TTCCACCA }\end{array}$ & $\begin{array}{l}\text { TAAAATCCATTTGCC } \\
\text { GGTTC }\end{array}$ & 56 & $184-207$ & Q. robur & $\begin{array}{l}\text { Not } \\
\text { assigned }\end{array}$ & $\begin{array}{l}\text { Chaperone protein dnaj } \\
\text { chloroplast }\end{array}$ \\
\hline
\end{tabular}

Note. ${ }^{\mathrm{b}}$ Putative function determined through a BLASTx search following the method in (Luro et al., 2008), ${ }^{\mathrm{g}}$ on Q. robur linkage map in either Durand et al. (2010) or Bodénès et al. (2012). All EST-SSRs were originally developed for Quercus robur (Durand et al. 2010) and adapted for North American red oak species (section Lobatae) (Sullivan et al. 2013, Lind-Riehl et al. 2014). 
Table 3. Mean genetic variation values for each marker across all samples.

\begin{tabular}{|c|c|c|c|c|c|c|c|c|c|c|c|c|}
\hline & FIR039 & FIR013 & FIR048 & FIR043 & PIE039 & GOT037 & PIE200 & FIR035 & VIT081 & VIT086 & PIE125 & FIR028 \\
\hline $\mathbf{N}_{\mathbf{a}}$ & 4.778 & 3.000 & 9.111 & 8.667 & 3.000 & 6.333 & 2.889 & 2.444 & 2.000 & 2.556 & 4.889 & 6.000 \\
\hline $\mathbf{H}_{\mathbf{o}}$ & 0.636 & 0.535 & 0.838 & 0.808 & 0.407 & 0.575 & 0.545 & 0.345 & 0.183 & 0.226 & 0.550 & 0.449 \\
\hline $\mathbf{H}_{\mathbf{e}}$ & 0.629 & 0.526 & 0.801 & 0.802 & 0.346 & 0.712 & 0.505 & 0.343 & 0.186 & 0.260 & 0.507 & 0.499 \\
\hline $\mathbf{F}$ & 0.0111 & -0.0171 & -0.0461 & 0.0074 & -0.1763 & 0.1924 & -0.0792 & 0.0058 & 0.0161 & 0.1307 & -0.0848 & 0.1002 \\
\hline
\end{tabular}


Table 4. Mean genetic variation estimates for each population.

\begin{tabular}{|c|c|c|c|c|c|c|}
\hline Population & $\mathbf{N}_{\mathbf{a}}$ & $\mathbf{H}_{\mathbf{0}}$ & $\mathbf{H}_{\mathbf{e}}$ & $\mathbf{F}$ & $\begin{array}{l}\text { No. of } \\
\text { private } \\
\text { alleles }\end{array}$ & $\begin{array}{c}\text { No. of locally } \\
\text { common alleles } \\
(\leq 25 \%)\end{array}$ \\
\hline DK & 4.583 & 0.497 & 0.480 & -0.035 & 0.000 & 0.417 \\
\hline CB & 5.000 & 0.567 & 0.568 & 0.001 & 0.333 & 0.500 \\
\hline ED & 5.000 & 0.525 & 0.516 & -0.017 & 0.167 & 0.250 \\
\hline WG & 4.333 & 0.499 & 0.506 & 0.013 & 0.083 & 0.333 \\
\hline PN & 4.167 & 0.447 & 0.471 & 0.050 & 0.333 & 0.167 \\
\hline $\mathbf{A M}$ & 5.333 & 0.507 & 0.574 & 0.116 & 0.167 & 0.250 \\
\hline SM & 4.750 & 0.493 & 0.501 & 0.015 & 0.083 & 0.250 \\
\hline MR & 4.667 & 0.490 & 0.479 & 0.023 & 0.083 & 0.167 \\
\hline $\mathbf{C R}$ & 3.917 & 0.547 & 0.491 & -0.114 & 0.083 & 0.250 \\
\hline
\end{tabular}

Private alleles are alleles that are found only in a single population among a broader collection of populations whereas locally common alleles $(\leq 25 \%)$ are present in $\leq 25 \%$ of populations. 
Table 5. HWE exact test (Cockerham, 1984) by locus in each population.

\begin{tabular}{|c|c|c|c|c|}
\hline \multicolumn{5}{|c|}{ DK } \\
\hline Locus & $\mathbf{H}_{\mathbf{0}}$ & $\mathbf{H}_{\mathbf{e}}$ & $\mathbf{F}$ & p-value \\
\hline FIR039 & 0.609 & 0.548 & -0.1103 & 1.0000 \\
\hline FIR013 & 0.955 & 0.658 & -0.4505 & 0.0237 \\
\hline FIR048 & 0.905 & 0.856 & -0.0570 & 0.6833 \\
\hline FIR043 & 0.667 & 0.822 & 0.1890 & 0.0681 \\
\hline PIE039 & 0.273 & 0.247 & -0.1046 & 1.0000 \\
\hline GOT037 & 0.636 & 0.536 & -0.1869 & 0.5628 \\
\hline PIE200 & 0.333 & 0.497 & 0.3287 & 0.0845 \\
\hline FIR035 & 0.292 & 0.249 & -0.1707 & 1.0000 \\
\hline VIT081 & 0.167 & 0.153 & -0.0909 & 1.0000 \\
\hline VIT086 & 0.083 & 0.081 & -0.0323 & 1.0000 \\
\hline PIE125 & 0.667 & 0.590 & -0.1294 & 0.5708 \\
\hline FIR028 & 0.375 & 0.523 & 0.2824 & 0.1690 \\
\hline \multicolumn{5}{|c|}{$\mathbf{C B}$} \\
\hline Locus & $\mathbf{H}_{\mathbf{0}}$ & $\mathbf{H e}_{\mathbf{e}}$ & $\mathbf{F}$ & p-value \\
\hline FIR039 & 0.591 & 0.510 & -0.1579 & 0.7003 \\
\hline FIR013 & 0.478 & 0.521 & 0.0817 & 0.6770 \\
\hline FIR048 & 1.000 & 0.848 & -0.1795 & 0.6867 \\
\hline FIR043 & 0.824 & 0.867 & 0.0499 & 0.0359 \\
\hline PIE039 & 0.750 & 0.735 & -0.0201 & 0.1048 \\
\hline GOT037 & 0.708 & 0.767 & 0.0769 & 0.6560 \\
\hline PIE200 & 0.167 & 0.288 & 0.4217 & 0.0553 \\
\hline FIR035 & 0.500 & 0.469 & -0.0667 & 1.0000 \\
\hline VIT081 & 0.208 & 0.249 & 0.1638 & 0.3976 \\
\hline VIT086 & 0.500 & 0.452 & -0.1056 & 0.8193 \\
\hline PIE125 & 0.542 & 0.596 & 0.0917 & 0.0058 \\
\hline FIR028 & 0.542 & 0.558 & 0.0295 & 0.5152 \\
\hline
\end{tabular}




\begin{tabular}{ccccc}
\hline Locus & $\mathbf{H}_{\mathbf{o}}$ & $\mathbf{H}_{\mathbf{e}}$ & $\mathbf{F}$ & p-value \\
\hline FIR039 & 0.714 & 0.687 & -0.0396 & 0.5387 \\
FIR013 & 0.636 & 0.563 & -0.1303 & 0.8851 \\
FIR048 & 0.913 & 0.774 & -0.1795 & 0.6923 \\
FIR043 & 0.750 & 0.866 & 0.1343 & 0.2234 \\
PIE039 & 0.708 & 0.484 & -0.4650 & 0.0602 \\
GOT037 & 0.458 & 0.589 & 0.2212 & 0.2663 \\
PIE200 & 0.391 & 0.446 & 0.1229 & 0.4628 \\
FIR035 & 0.333 & 0.278 & -0.2000 & 1.0000 \\
VIT081 & 0.042 & 0.041 & -0.0213 & - \\
VIT086 & 0.083 & 0.155 & 0.4637 & 0.1276 \\
PIE125 & 0.750 & 0.629 & -0.1917 & 0.8439 \\
FIR028 & 0.522 & 0.679 & $\mathbf{0 . 2 3 1 2}$ & 0.0000 \\
\hline
\end{tabular}

\begin{tabular}{ccccc}
\hline Locus & \multicolumn{5}{l}{ WG } & \\
\hline FIR039 & $\mathbf{H}_{\mathbf{o}}$ & $\mathbf{H}_{\mathbf{e}}$ & $\mathbf{F}$ & p-value \\
FIR013 & 0.632 & 0.633 & 0.0022 & 0.4249 \\
FIR048 & 0.609 & 0.499 & -0.2197 & 0.4212 \\
FIR043 & 0.864 & 0.811 & -0.0650 & 0.5446 \\
PIE039 & 0.833 & 0.839 & 0.0072 & 0.1420 \\
GOT037 & 0.417 & 0.359 & -0.1622 & 1.0000 \\
PIE200 & 0.591 & 0.707 & 0.1637 & 0.2825 \\
FIR035 & 0.292 & 0.353 & 0.1744 & 0.5533 \\
VIT081 $*$ & 0.208 & 0.187 & -0.1163 & 1.0000 \\
VIT086 & 0.043 & 0.043 & -0.0222 & - \\
PIE125 & 0.500 & 0.477 & -0.0492 & 0.2785 \\
FIR028 & 0.583 & 0.648 & 0.0992 & 0.3547 \\
& 0.417 & 0.519 & 0.1973 & 0.0400
\end{tabular}




\begin{tabular}{|c|c|c|c|c|}
\hline FIR048 & 0.458 & 0.575 & 0.2024 & 0.0818 \\
\hline FIR043 & 0.708 & 0.778 & 0.0893 & 0.6377 \\
\hline PIE039 & 0.125 & 0.119 & -0.0511 & 1.0000 \\
\hline GOT037 & 0.667 & 0.732 & 0.0890 & 0.0689 \\
\hline PIE200 & 0.833 & 0.611 & -0.3636 & 0.0056 \\
\hline FIR035 & 0.375 & 0.305 & -0.2308 & 0.5512 \\
\hline VIT081 & 0.333 & 0.424 & 0.2147 & 0.4963 \\
\hline VIT086 & 0.238 & 0.427 & 0.4430 & 0.0495 \\
\hline PIE125 & 0.250 & 0.226 & -0.1077 & 1.0000 \\
\hline FIR028 & 0.167 & 0.156 & -0.0667 & 1.0000 \\
\hline \multicolumn{5}{|c|}{ AM } \\
\hline Locus & $\mathbf{H}_{\mathbf{0}}$ & $\mathbf{H}_{\mathbf{e}}$ & $\mathbf{F}$ & p-value \\
\hline FIR039 & 0.591 & 0.685 & 0.1373 & 0.0932 \\
\hline FIR013 & 0.417 & 0.444 & 0.0625 & 1.0000 \\
\hline FIR048 & 0.739 & 0.839 & 0.1194 & 0.0513 \\
\hline FIR043 & 0.833 & 0.882 & 0.0551 & 0.3658 \\
\hline PIE039 & 0.500 & 0.404 & -0.2379 & 0.7764 \\
\hline GOT037 & 0.318 & 0.793 & 0.5990 & 0.0000 \\
\hline PIE200 & 0.750 & 0.659 & -0.1383 & 0.0530 \\
\hline FIR035 & 0.292 & 0.415 & 0.2971 & 0.0383 \\
\hline VIT081 & 0.292 & 0.249 & -0.1707 & 1.0000 \\
\hline VIT086 & 0.125 & 0.117 & -0.0667 & 1.0000 \\
\hline PIE125 & 0.667 & 0.659 & -0.0119 & 0.4492 \\
\hline FIR028 & 0.565 & 0.744 & 0.2402 & 0.0185 \\
\hline \multicolumn{5}{|c|}{ SM } \\
\hline Locus & $\mathbf{H}_{\mathbf{o}}$ & $\mathrm{He}_{\mathrm{e}}$ & $\mathbf{F}$ & p-value \\
\hline FIR039 & 0.591 & 0.628 & 0.0592 & 0.4391 \\
\hline FIR013 & 0.348 & 0.468 & 0.2566 & 0.3340 \\
\hline FIR048 & 0.826 & 0.845 & 0.0224 & 0.3878 \\
\hline FIR043 & 0.783 & 0.830 & 0.0569 & 0.0552 \\
\hline PIE039 & 0.348 & 0.287 & -0.2105 & 1.0000 \\
\hline
\end{tabular}




\begin{tabular}{|c|c|c|c|c|}
\hline GOT037 & 0.524 & 0.706 & 0.2584 & 0.0334 \\
\hline PIE200 & 0.636 & 0.533 & -0.1938 & 0.5766 \\
\hline FIR035 & 0.435 & 0.386 & -0.1275 & 1.0000 \\
\hline VIT081 & 0.478 & 0.364 & -0.3143 & 0.2742 \\
\hline VIT086 & 0.130 & 0.198 & 0.3397 & 0.2128 \\
\hline PIE125 & 0.364 & 0.319 & -0.1392 & 1.0000 \\
\hline FIR028 & 0.455 & 0.452 & -0.0046 & 0.2500 \\
\hline \multicolumn{5}{|c|}{ MR } \\
\hline Locus & $\mathbf{H}_{\mathbf{O}}$ & $\mathrm{He}_{\mathbf{e}}$ & $\mathbf{F}$ & p-value \\
\hline FIR039 & 0.583 & 0.574 & -0.0166 & 0.5846 \\
\hline FIR013 & 0.375 & 0.471 & 0.2044 & 0.4518 \\
\hline FIR048 & 0.917 & 0.839 & -0.0932 & 0.8283 \\
\hline FIR043 & 0.875 & 0.779 & -0.1237 & 0.2438 \\
\hline PIE039 & 0.000 & 0.000 & - & - \\
\hline GOT037 & 0.667 & 0.782 & 0.1476 & 0.0435 \\
\hline PIE200 & 0.667 & 0.530 & -0.2570 & 0.3371 \\
\hline FIR035 & 0.500 & 0.584 & 0.1441 & 0.4440 \\
\hline VIT081 & 0.000 & 0.000 & - & - \\
\hline VIT086 & 0.000 & 0.080 & 1.0000 & 0.0210 \\
\hline PIE125 & 0.667 & 0.560 & -0.1907 & 0.6089 \\
\hline FIR028 & 0.625 & 0.551 & -0.1339 & 1.0000 \\
\hline \multicolumn{5}{|c|}{ CR } \\
\hline Locus & $\mathbf{H}_{\mathbf{0}}$ & $\mathrm{H}_{\mathrm{e}}$ & $\mathbf{F}$ & p-value \\
\hline FIR039 & 0.667 & 0.669 & 0.0039 & 0.2623 \\
\hline FIR013 & 0.542 & 0.574 & 0.0560 & 0.8198 \\
\hline FIR048 & 0.917 & 0.819 & -0.1186 & 0.5243 \\
\hline FIR043 & 1.000 & 0.556 & -0.7972 & 0.0000 \\
\hline PIE039 & 0.542 & 0.478 & -0.1325 & 0.8896 \\
\hline GOT037 & 0.609 & 0.796 & 0.2352 & 0.0644 \\
\hline PIE200 & 0.833 & 0.625 & -0.3333 & 0.0017 \\
\hline FIR035 & 0.167 & 0.219 & 0.2381 & 0.2987 \\
\hline
\end{tabular}




$\begin{array}{lllll}\text { VIT081 } & 0.083 & 0.153 & 0.4545 & 0.1283 \\ \text { VIT086 } & 0.375 & 0.353 & -0.0614 & 1.0000 \\ \text { PIE125 } & 0.458 & 0.380 & -0.2055 & 1.0000 \\ \text { FIR028 } & 0.375 & 0.312 & -0.2033 & 1.0000\end{array}$

Significant values in boldface type are significantly different from Hardy-Weinberg proportions $(\alpha=0.05)$ after Bonferroni correction $(\mathrm{p}<0.05 / 12=0.00416) . *$ : no $\mathrm{p}$-value was calculated for this marker with very low variation within population WG. 
Table 6. Pairwise genetic distances ( $\mathrm{F}_{\mathrm{ST}}$ ) between populations.

\begin{tabular}{|c|c|c|c|c|c|c|c|c|c|}
\hline Population & DK & CB & ED & WG & PN & $\mathbf{A M}$ & SM & MR & $\mathbf{C R}$ \\
\hline DK & 0.000 & & & & & & & & \\
\hline CB & 0.054 & 0.000 & & & & & & & \\
\hline ED & 0.028 & 0.048 & 0.000 & & & & & & \\
\hline WG & 0.028 & 0.038 & 0.035 & 0.000 & & & & & \\
\hline PN & 0.129 & 0.094 & 0.125 & 0.111 & 0.000 & & & & \\
\hline $\mathbf{A M}$ & 0.075 & 0.065 & 0.065 & 0.079 & 0.058 & 0.000 & & & \\
\hline SM & 0.087 & 0.066 & 0.077 & 0.092 & 0.046 & 0.025 & 0.000 & & \\
\hline MR & 0.115 & 0.087 & 0.102 & 0.115 & 0.083 & 0.049 & 0.049 & 0.000 & \\
\hline CR & 0.083 & 0.060 & 0.077 & 0.062 & 0.050 & 0.039 & 0.034 & 0.070 & 0.000 \\
\hline
\end{tabular}


Table 7. Pairwise geographic distance in kilometers between populations.

\begin{tabular}{|c|c|c|c|c|c|c|c|c|c|}
\hline Population & DK & CB & ED & WG & PN & $\mathbf{A M}$ & SM & MR & CR \\
\hline DK & 0.000 & & & & & & & & \\
\hline CB & 82.39 & 0.000 & & & & & & & \\
\hline ED & 176.3 & 152.07 & 0.000 & & & & & & \\
\hline WG & 162.98 & 103.21 & 245.81 & 0.000 & & & & & \\
\hline PN & 57.22 & 97.5 & 138.03 & 200.52 & 0.000 & & & & \\
\hline $\mathbf{A M}$ & 134.97 & 71.74 & 212.13 & 38.7 & 167.92 & 0.000 & & & \\
\hline SM & 147.35 & 76.76 & 203.73 & 43.36 & 172.56 & 13.91 & 0.000 & & \\
\hline MR & 285.16 & 314.88 & 199.45 & 420.3 & 233.94 & 389.52 & 388.27 & 0.000 & \\
\hline $\mathbf{C R}$ & 61.99 & 50.84 & 192.92 & 101.51 & 105.01 & 75.42 & 91.57 & 339.27 & 0.000 \\
\hline
\end{tabular}




\section{Figures}

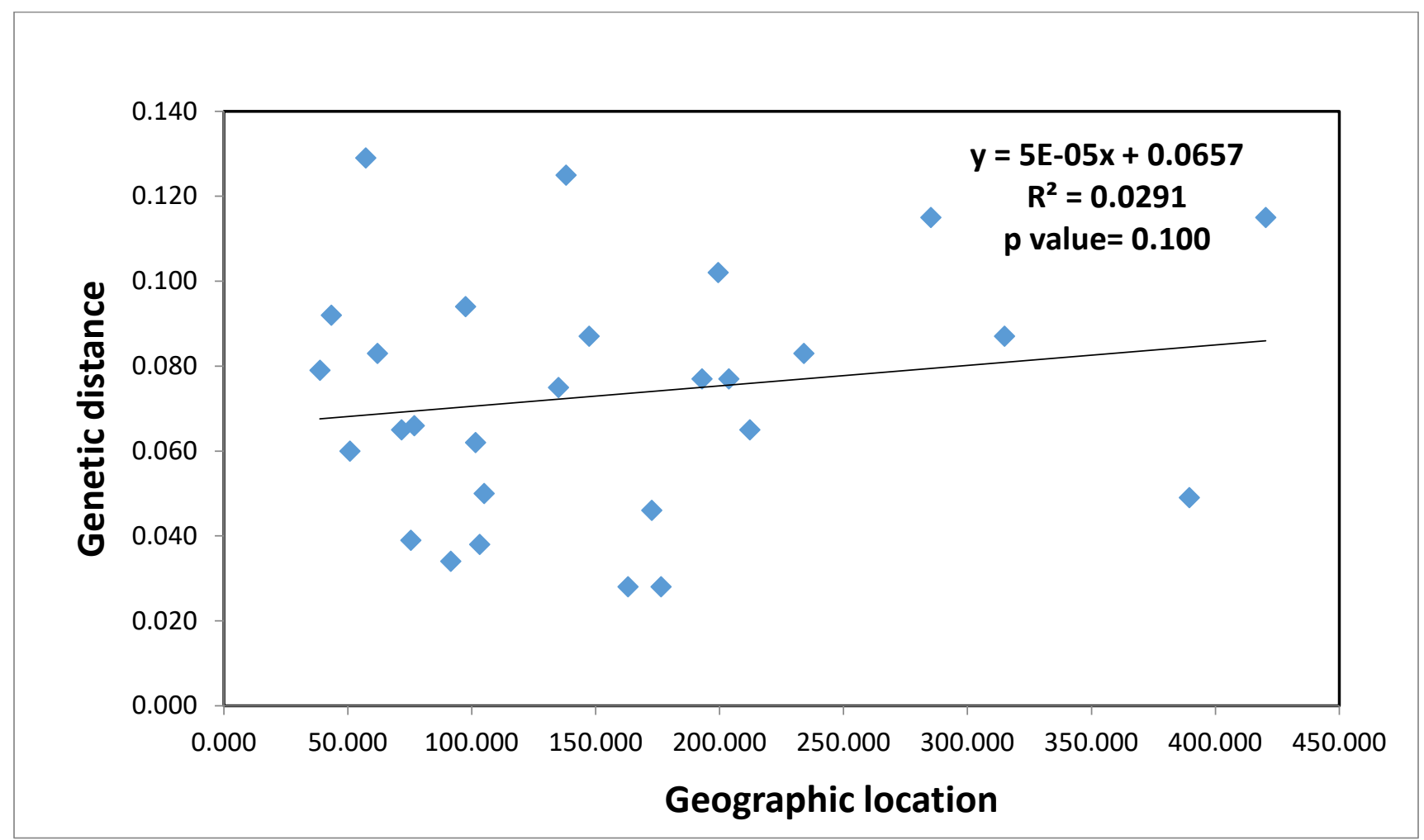

Figure 1. Geographic distance (measured in kilometers) versus genetic distance for pairwise comparisons of nine populations of Quercus georgiana using a Mantel test. 


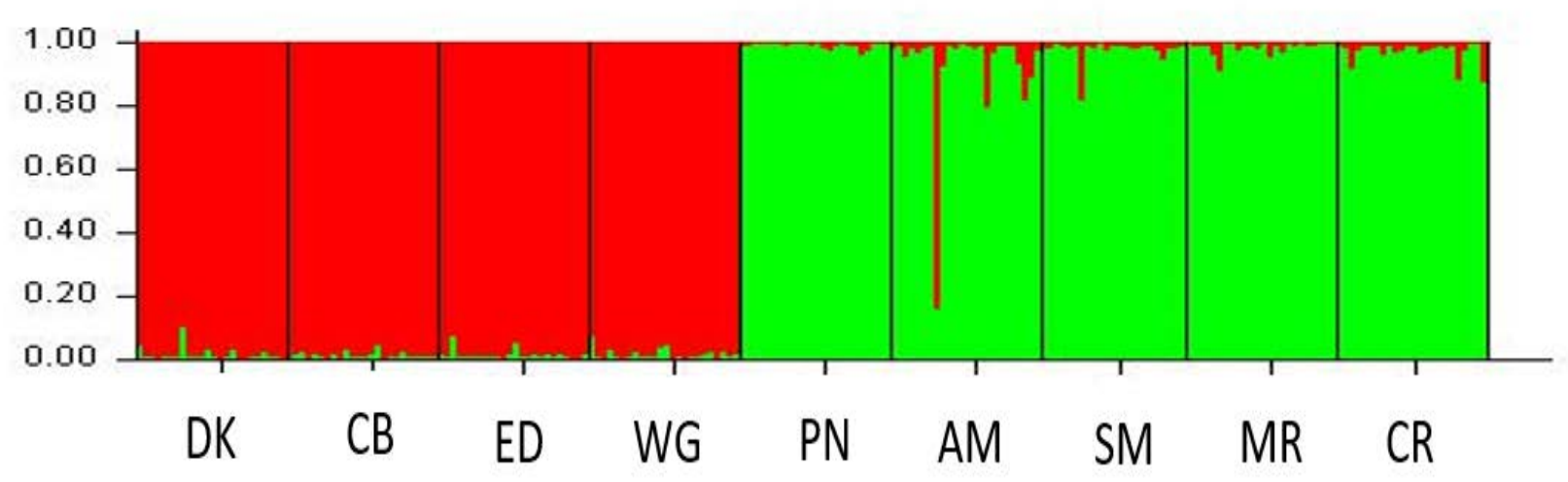

Figure 2. Genetic assignment of individuals using the Bayesian method in STRUCTURE 2.3.4 (Pritchard et al. 2000). Individuals are grouped by population. 


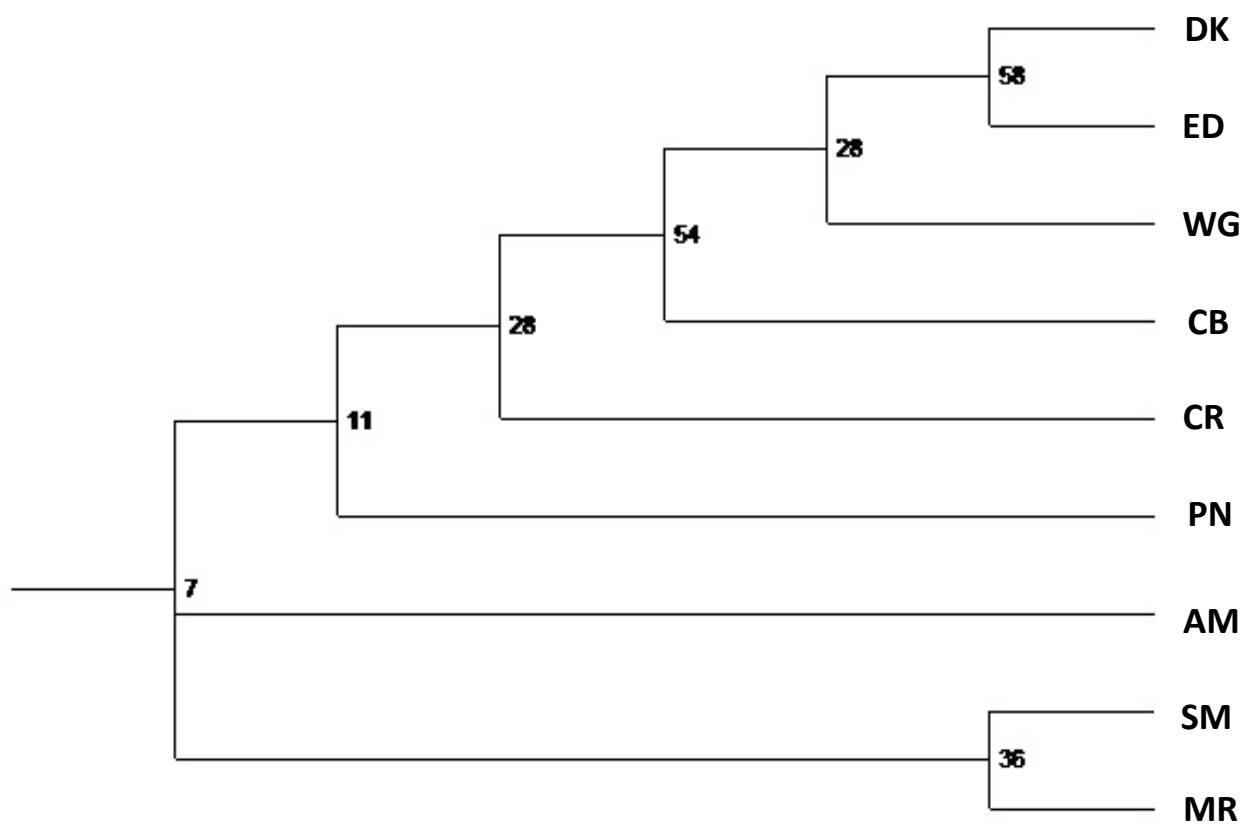

Figure 3. Dendrogram (Neighbor joining method) based on Cavalli-Sforza and Edwards (1967) genetic distances at EST-SSRs; numbers at nodes are percentages over 1,000 bootstrap replicates using Populations 2.0 (Langella 1999). 


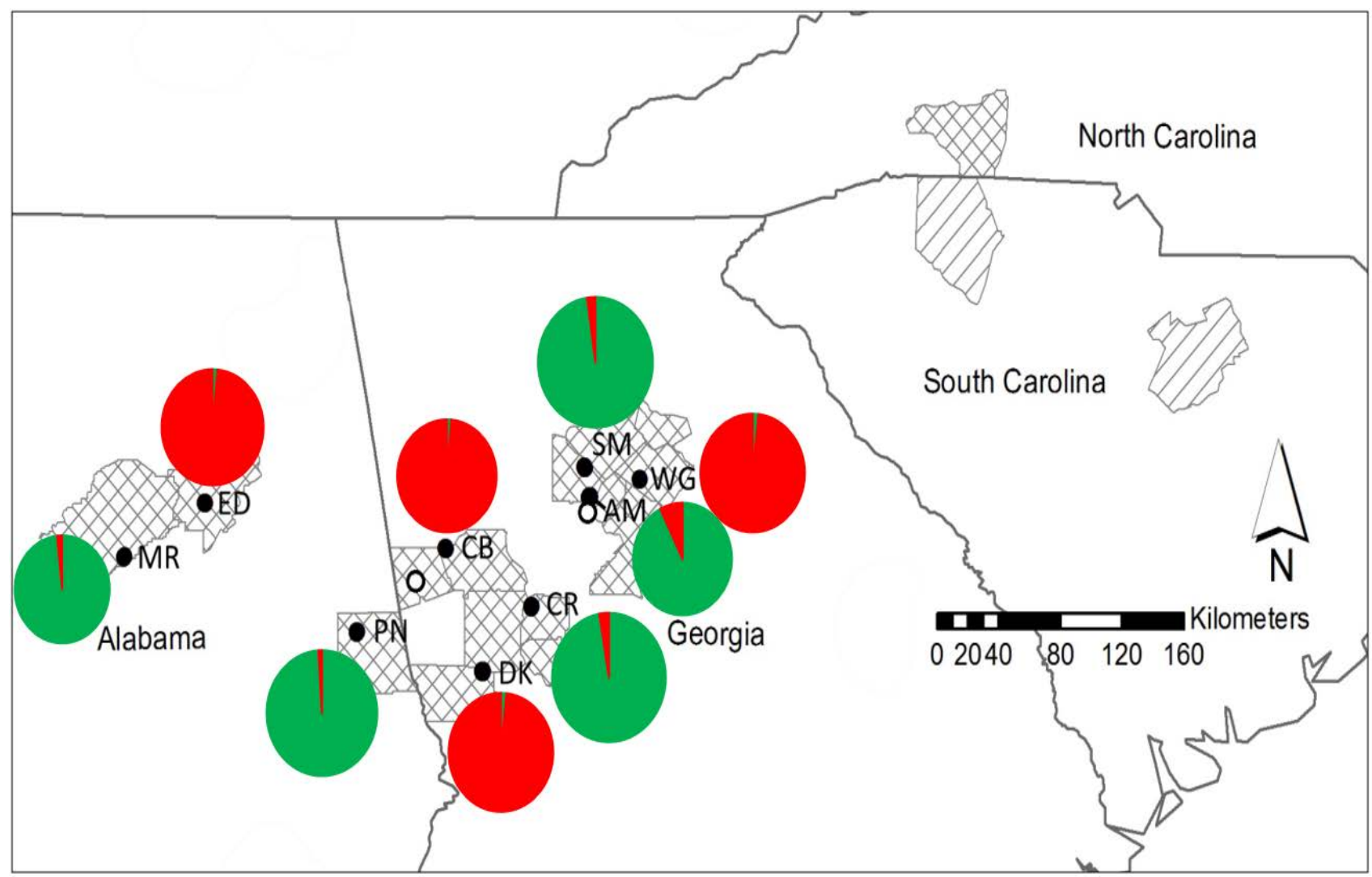

Figure 4. Geographic distribution of percentage of ancestry per population as inferred in STRUCTURE. Geographic distribution of genetic cluster 1 (red) and cluster 2 (green). 


\section{References}

Backs, R. J., Terry, M. and Ashley, M. 2016. Using genetic analysis to evaluate hybridization as a conservation concern for the threatened species Quercus hinckleyi C. H. Muller (Fagaceae). Int. J. Plant Sci 177(2): 122-131.

Bodenes, C., Chancerel, E., Gailing, O., Vendramin, G.G., Bagnoli, F., Durand, J., Goicoechea, P.G., Soliani, C., Villani, F., Mattioni, C., Koelewijn, H.P., Murat, F., Salse, J., Roussel, G., Boury, C., Alberto, F., Kremer, A. and Plomion, C. 2012. Comparative mapping in the Fagaceae and beyond with EST-SSRs. BMC Plant Biology 12:153.

Cockerham, B. S. W. a. C. C. 1984. Estimating F-Statistics for the analysis of population structure. Evolution 38(6): 1358-1370.

Conesa, A., Gotz, S., Garcia-Gomez, J. M., Terol, J., Talon, M. and Robles, M. 2005. Blast2GO: a universal tool for annotation, visualization and analysis in functional genomics research. Bioinformatics 21: 3674-3676.

Durand, J., Bodenes, C., Chancerel, E., Frigerio, J-M., Vendramin, G., Sebastiani, F., Buonamici, A., Gailing, O., Koelewijn, H-P., Villani, F., Mattioni, C., Cherubini, M., Goicoechea, P.G., Herran, A., Ikaran, Z., Cabane, C., Ueno, S., Alberto, F., Dumoulin, P-Y., Guichoux, E., de Daruvar, A., Kremer, A. and Plomion, C. 2010. A fast and cost-effective approach to develop and map EST-SSR markers: oak as a case study. BMC Genomics 11:570.

Ellis, J. R. and Burke, J. M. 2007. EST-SSRs as a resource for population genetic analyses. Heredity (Edinb), 99: 125-32.

Keiper, F. J., Hayden, M.J., Park, R. F. and Wellings, C. R. 2003. Molecular genetic variability of Australian isolates of five cereal rust pathogens. Mycological Research 107: 545-556.

Kramer, A., A. Hird, K. Shaw, M. Dosmann, and R. Mims. 2011. Conserving North America’s Threatened Plants: Progress Report on Target 8 of the Global Strategy for Plant Conservation: Botanic Gardens Conservation International U.S.

Langella, O. 1999. Populations 1.2.30: a population genetic software.

Ledig, F. T. 1988. The Conservation of Diversity in Forest Trees. Bioscience 38 No 7: 471-473.

Lind, J. and Gailing, O. 2013. Genetic structure of Quercus rubra L. and Quercus ellipsoidalis E. J. Hill populations at gene-based EST-SSR and nuclear SSR markers. Tree Genetics \& Genomes 9:707-722.

Lind-Riehl, J., Sullivan, A. and Gailing, O. 2014. Evidence for selection on a CONSTANS-like gene between two red oak species. Annals of Botany 113: 967-975. 
Luro, F. L., Costantino, G., Terol, J., Argout, X., Allario, T., Wincker, P., Morillon, R. 2008. Transferability of the EST-SSRs developed on Nules clementine (Citrus clementina Hort ex Tan) to other Citrus species and their effectiveness for genetic mapping. BMC Genomics 9: 287.

Nei, M. 1973. Analysis of gene diversity in subdivided populations. Proceedings of the National Academy of Sciences USA 70: 3321-3323.

Oldfield, S. and A. Eastwood. 2007. The Red List of Oaks. Fauna \& Flora International, Cambridge, UK.

Peakall, R. and Smouse, P.E. 2006. GENEALEX 6: genetic analysis in Excel. Population genetic software for teaching and research. Molecular Ecology Notes 6:288-295.

Pence, V. 2012. The possibilities and challenges of in vitro methods for plant conservation. Kew Bulletin 64.

Pritchard, J.K., Stephens, M. and Donnelly, P. 2000. Inference of population structure using multilocus genotype data. Genetics 155:945-959.

Raymond, M. and Rousset, F. 1995. GENEPOP (Version 1.2): population genetics software for exact tests and ecumenicism. $J$ Hered 86:248-249.

Reed, D.H., and R. Frankham. 2003. Correlation between fitness and genetic diversity. Conservation Biology. 17(1):230-237.

Rousset, F. 2008. Genepop’007: a complete re-implementation of the genepop software for Windows and Linux. Molecular Ecology Resources 8:103-106.

Sertse, D., Gailing, O., Eliades, N. and Finkeldey, R. 2013. Transferability and application of microsatellites (SSRs) from Juniperus communis L. to Juniperus procera Hochst. Ex endl. Open Journal of Genetics 3: 115-126.

Sork, V., Huang, S. and Wiener, E. 1993. Macrogeographic and fine-scale genetic structure in a North American oak species, Quercus rubra L. Ann For Sci 50:261-270.

Steferon, V. M., Gailing, O. and Finkeldey, R. 2008. The role of gene flow in shaping genetic structures of the subtropical conifer species Araucaria angustifolia. Plant Biology 10: 356364.

Sullivan, A. R., Lind, J. F., McCleary, T. S., Romero-Severson, J., and Gailing, O. 2013. Development and characterization of genomic and gene-based microsatellite markers in North American red oak species. Plant Molecular Biology Reporter 31: 231-239.

Toppila, R. 2012. Ex-situ conservation of oak (Quercus L.) in botanic gardens: A North American perspective. Master of Science thesis, University of Delaware. 
Vazquez, D., and Gittleman,J. 1998. Biodiversity conservation: Does phylogeny matter? Current Biology 8, no. 11.

Wenzell, K. \& Kenny, L. 2015. Quercus georgiana. The IUCN Red List of Threatened Species 2015.

Whitlock, R., Hipperson, H., Thompson, D.B.A., Butlin, R.K. and Burke, T. 2016. Consequences of in-situ strategies for the conservation of plant. Biological Conservation 203: 134-142.

Wright, S. 1965. The interpretation of population structure by F-statistics with special regards to systems of mating. Evolution 19: 395-420.

http://globaltrees.org/threatened-trees/trees/quercus-georgiana/ 